OPEN ACCESS

Edited by:

Damer Blake

Royal Veterinary College (RVC),

United Kingdom

Reviewed by:

Sergio Eduardo Bermúdez, Gorgas Memorial Institute of Health

Studies, Panama

Jose Reck,

Instituto de Pesquisas Veterinárias Desidério Finamor (IPVDF), Eldorado

do Sul, Brazil

${ }^{*}$ Correspondence:

Álvaro A. Faccini-Martínez afaccini@gmail.com; alfaccin@utmb.edu

Specialty section: This article was submitted to Parasitology,

a section of the journal

Frontiers in Veterinary Science

Received: 02 May 2021 Accepted: 25 May 2021

Published: 23 June 2021

Citation:

López Y, Robayo-Sánchez LN, Muñoz-Leal S, Aleman A, Arroyave E, Ramírez-Hernández A,

Cortés-Vecino JA, Mattar S and

Faccini-Martínez ÁA (2021) Ornithodoros puertoricensis (Ixodida: Argasidae) Associated With Domestic Fowl in Rural Dwellings From Córdoba Department, Caribbean Colombia. Front. Vet. Sci. 8:704399 doi: 10.3389/fvets.2021.704399

\section{Ornithodoros puertoricensis (Ixodida: Argasidae) Associated With Domestic Fowl in Rural Dwellings From Córdoba Department, Caribbean Colombia}

Yesica López ${ }^{1}$, Laura Natalia Robayo-Sánchez ${ }^{2}$, Sebastián Muñoz-Leal ${ }^{3}$, Ader Aleman ${ }^{1}$, Esteban Arroyave ${ }^{4}$, Alejandro Ramírez-Hernández ${ }^{2}$, Jesús Alfredo Cortés-Vecino ${ }^{2}$, Salim Mattar ${ }^{1}$ and Álvaro A. Faccini-Martínez ${ }^{4 *}$

1 Instituto de Investigaciones Biológicas del Trópico, Universidad de Córdoba, Monteria, Colombia, ${ }^{2}$ Grupo Parasitología Veterinaria, Departamento de Salud Animal, Facultad de Medicina Veterinaria y de Zootecnia, Universidad Nacional de Colombia, Bogotá, Colombia, ${ }^{3}$ Departamento de Ciencia Animal, Facultad de Ciencias Veterinarias, Universidad de Concepción, Chillan, Chile, ${ }^{4}$ Department of Pathology, University of Texas Medical Branch, Galveston, TX, United States

Ticks of genus Ornithodoros are nidicolous parasites associated with a wide array of vertebrates. In humans, their bites cause hypersensitivity reactions and are capable to transmit pathogens of health concern. In the department of Córdoba, Caribbean region of Colombia, the first report of an Ornithodoros soft tick was made in 1980 by Betancourt, who described the collection of Ornithodoros talaje in human dwellings. Nevertheless, current the records of $O$. talaje made in South America have been questioned and likely correspond to misidentifications with morphologically similar species. Between October and December of 2020, we visited rural areas of four localities from three municipalities within the department of Córdoba: Cuero Curtido and Severá (municipality of Cereté), El Espanto (municipality of Planeta Rica), and Arroyo Negro (municipality of San Carlos). Search for soft ticks was performed in 46 human domiciles and peridomiciliary areas. We searched in areas frequented by domestic animals, inspecting cracks in the walls and fowl nests. Infestation by soft ticks was found in 13\% (6/46) of visited houses. Overall, 215 ticks were collected (26 larvae, 144 nymphs and 45 adults) from nests of domestic birds or in the adjacent walls. Larvae, nymphs and adults were morphologically identified as Ornithodoros puertoricensis. Molecular identification of ticks was confirmed by sequencing the tick mitochondrial $16 \mathrm{~S}$ gene of adults, pools of nymphs and larvae. Pairwise comparisons showed a 99\% of identity with O. puertoricensis from Panama. This study reports for the first time $O$. puertoricensis associated with domestic fowl in rural dwellings in Colombia, and expands the geographical distribution of this tick species toward the Córdoba department. Importantly, local people described exposure to tick bites while sleeping in infested houses; therefore, the transmission of soft tick-borne pathogens is now of concern in the region.

Keywords: soft ticks, parasites, fowl nests, domiciliary infestation, Ornithodoros, Colombia 


\section{INTRODUCTION}

Ticks of the genus Ornithodoros are nidicolous arthropods that parasite a wide range of vertebrates, such as reptiles, birds and mammals, including humans (1). The saliva of Ornithodoros ticks can cause toxicosis (hypersensitivity and immunological response ranging from mild dermal lesions to systemic disease) (2) and transmit pathogenic agents, such as tick-borne relapsing fever (TBRF) group borreliae, to humans and domestic animals (3). Particularly in South America, Ornithodoros brasiliensis, Ornithodoros fonsecai, Ornithodoros mimon, Ornithodoros rietcorreai, Ornithodoros rioplatensis, Ornithodoros rostratus, and Ornithodoros spheniscus cause toxicosis (4-10). Moreover, human cases of TBRF were described during the first decade of the 20th century mainly in Colombia and Venezuela, and Ornithodoros rudis was involved as the vector (11-13). Interestingly, in the last two decades, studies have molecularly identified putative novel species of relapsing fever group borreliae in countries without reported cases, such as Chile and Brazil $(14,15)$.

In Colombia, while the study of TBRF vanished decades ago, 10 species of Ornithodoros are known to occur, namely Ornithodoros azteci, Ornithodoros furcosus, Ornithodoros hasei, Ornithodoros marinkellei, Ornithodoros marmosae, Ornithodoros peropteryx, Ornithodoros puertoricensis, Ornithodoros rossi, Ornithodoros talaje, and Ornithodoros yumatensis (16). Noteworthy, O. rudis, O. furcosus, and O. puertoricensis have been reported infesting human dwellings in the country (17-19). Adults of some Neotropical soft ticks are morphologically similar, and early reports of these three species was subject of confusion in Central and South America $(16,17)$. Therefore, old reports of Ornithodoros spp. made in Colombia need confirmation.

Ornithodoros puertoricensis was reported in Colombia for the first time in Ayacucho, in Cesar department, Caribbean region (20). Several years later, Betancourt (21) made the sole record of an Ornithodoros soft tick in the department of Córdoba (also in the Caribbean region). Specifically, the specimens were collected inside human dwellings at San Carlos municipality. At that time, the ticks were sent to the University of California and identified as O. talaje (21). Currently, the records of $O$. talaje made in South America have been questioned $(16,22)$ and likely correspond to misidentifications with morphologically similar species of the group. Therefore, the species reported by Betancourt (21) remains to be confirmed.

Fowl are common host for soft ticks of genus Argas (23) and there is evidence that Ornithodoros spp. ticks do parasitize domestic birds in Central America (20). Although 10 species of Ornithodoros occur in Colombia, fowl have never been implicated as hosts.

We carried out a prospective study in order to confirm the presence and identity of neglected Ornithodoros in rural dwellings from the department of Córdoba, including the San Carlos municipality. Our results demonstrate that soft ticks do occur in that region of Colombia and infest fowl nests.

\section{MATERIALS AND METHODS}

\section{Geographic Area and Sampling Sites}

Between October and December of 2020, we visited rural areas of four localities in three municipalities within the department of Córdoba, Colombia: Cuero Curtido ("locality 1") and Severá (“locality 3”) (N 08 55’53" -W 75 57’31" and N $08^{\circ} 90^{\prime} 77^{\circ}$ " -W $75^{\circ} 87^{\prime} 54^{\prime \prime}$, respectively) in the municipality of Cereté; El Espanto ("locality 2") (N $\left.08^{\circ} 31^{\prime} 46^{\prime \prime}-\mathrm{W} 75^{\circ} 39^{\prime} 51^{\prime \prime}\right)$ in the municipality of Planeta Rica; and Arroyo Negro ("locality 4") (N $08^{\circ} 42$ '46" -W $75^{\circ} 40^{\prime} 21^{\prime \prime}$ ) in the municipality of San Carlos (Figure 1).

The three municipalities share similar environmental conditions $(12-87 \mathrm{~m}$ of altitude, temperature between 25 and $28^{\circ} \mathrm{C}$, and average relative humidity of $81 \%$ ) (24-26). Municipality of Cereté has a population of 105,815 inhabitants (26), Planeta Rica of 64,205 inhabitants (24), and San Carlos of 23,532 inhabitants (25). The four visited localities were selected by convenience criteria, considering the easiness of access, and the researchers' safety regarding public order conditions in the area.

Searches for Ornithodoros ticks were performed in 46 human domiciles and peridomiciliary areas (eight houses in locality 1, three in locality 2, eight in locality 3 , and twenty-seven in locality 4 ). The houses were constructed with wood, "bahareque" (clay or mud with sticks or canes), and "guadua" (woody bamboo) in their walls, reinforced with cardboard. All had dirt floors and palm leaves as roofs. The presence of domestic animals such as dogs, cats, pigs, chickens, turkeys, and ducks was common in all investigated houses, and the animals circulated freely inside the houses and in the peridomiciliary area. We examined domestic animals' resting areas, chicken coops, and nests of chickens, ducks and turkeys. Around these areas, cracks in the walls and nest debris were inspected. Inspections inside the inhabitants' rooms were not allowed for privacy reasons in most of the houses.

\section{Tick Collection and Identification}

While larvae, nymphs, adults and exuviae were collected in $70 \%$ ethanol, eggs were maintained alive, transported to the laboratory, and kept in darkness inside an incubator $\left(25^{\circ} \mathrm{C}\right.$, $80 \%$ relative humidity). Hatched larvae were mounted onto slides with Hoyer's medium and examined by light microscopy for morphological identification (27). A subset of adults was prepared for scanning electron microscopic examinations for greater definition of morphological characteristics. Larvae were morphologically identified following taxonomical keys (28). Morphological identification of adults and nymphs was done with original descriptions of Ornithodoros spp. $(27,29)$.

\section{Molecular and Phylogenetic Analyses}

Morphological identification of ticks was complemented by molecular analysis. For this purpose, DNA extraction (QIAGEN DNeasy Blood \& Tissue kit) was performed on individual adults, and larvae and nymphs of each locality were pooled (up to 10 larvae, up to 4 nymphs). Successful extractions were confirmed by PCR targeting the tick mitochondrial 16 S gene for each sample 

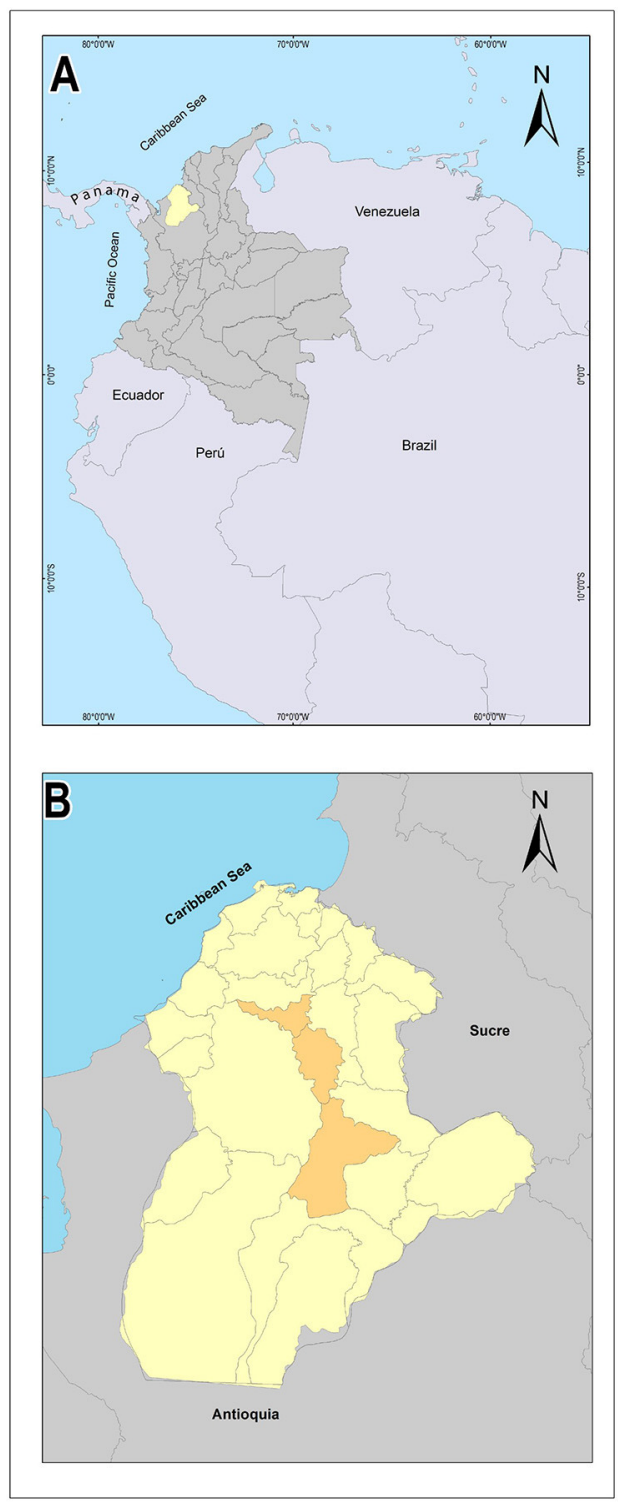

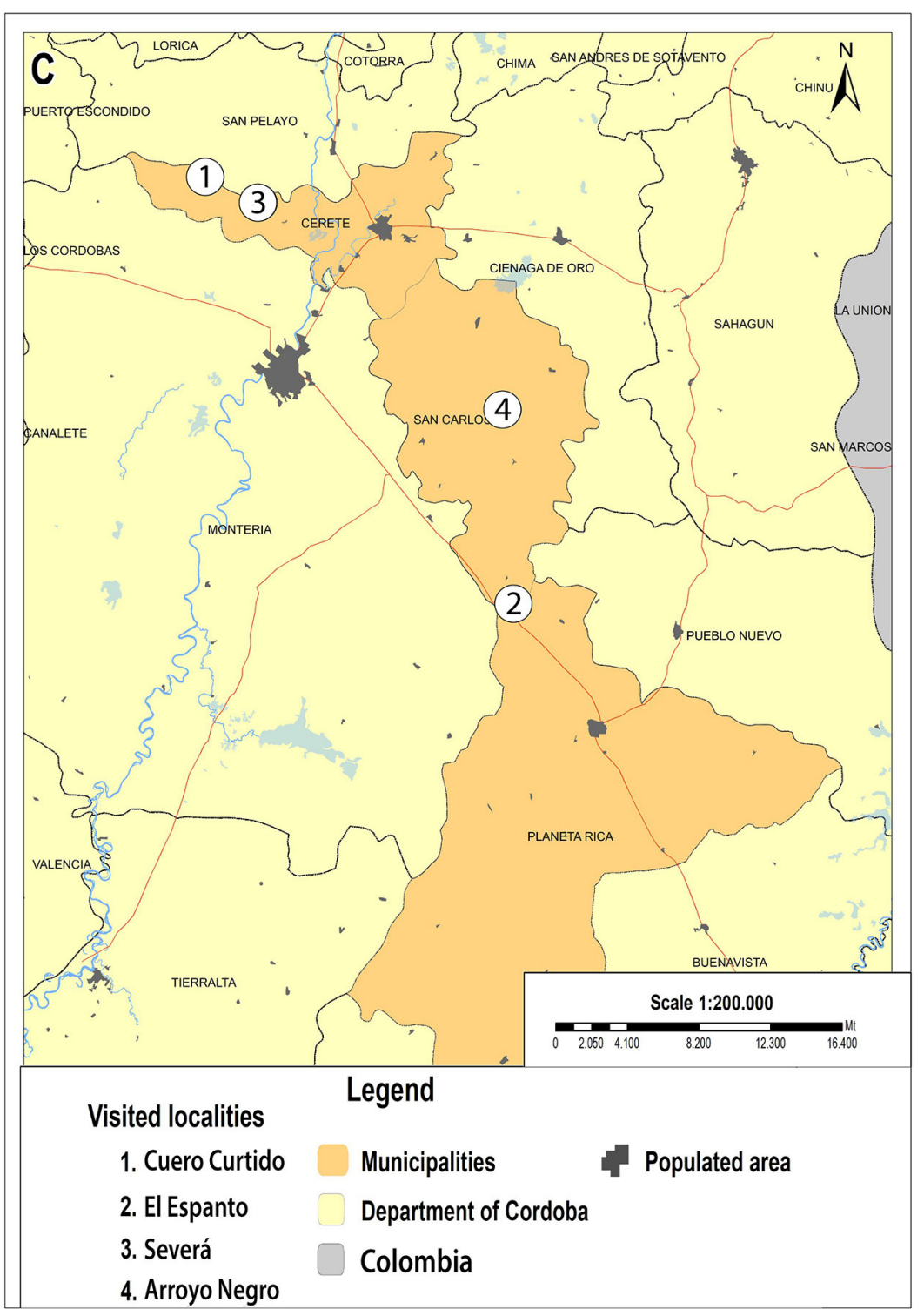

FIGURE 1 | Map showing the collection locations. (A) Map of South America showing the location of Córdoba department within Colombia. (B) Map of Córdoba department showing the investigated municipalities. (C) Studied localities within the Cereté, San Carlos, and Planeta Rica municipalities.

with primers described elsewhere (30). Amplicons of expected size were Sanger-sequenced at the Molecular Genomics Core of the University of Texas Medical Branch (Galveston, TX). Obtained sequences were assembled with Geneious (31) and the consensuses compared with sequences available in GenBank using BLASTn (32).

An alignment with 33 sequences of Argasidae retrieved from GenBank was constructed in MAFFT (33). A phylogenetic analysis using the approximately maximum likelihood method was implemented in FastTree 2 (34), selecting the GTR model and five rates categories of sites. Ornithodoros brasiliensis (GU198363) and Ornithodoros rostratus (DQ295780) sequences rooted the tree.

\section{RESULTS}

\section{Tick Collection}

Infestation by Ornithodoros ticks was found in $12 \%(1 / 8)$ of the visited houses in locality 1 , in $33 \%(1 / 3)$ of locality 2 , in $25 \%$ $(2 / 8)$ of locality 3 , and $7 \%(2 / 27)$ of locality 4 . Overall, 215 ticks were collected (26 larvae, 144 nymphs, 13 females, and 32 males) (Table 1). All were found in fowl nests and on adjacent walls. Briefly, 48 ticks were collected in locality 1 , of which eight were adults (males) and 40 were nymphs, all collected in a hen's nest in the kitchen of a house with a dirt floor and cardboard-reinforcedwooden walls (Figures 2C,D). In locality 2 we found exuviae during inspection of the substrate (soil/sand) of a chicken nest 
TABLE 1 | Ornithodoros spp. collected in rural dwellings from Córdoba department, Colombia.

\begin{tabular}{|c|c|c|c|c|c|}
\hline Municipality & Locality & Collection area & $\begin{array}{l}\text { Total of collected } \\
\text { specimens }\end{array}$ & $\begin{array}{l}\text { Number of ticks } \\
\text { submitted to } \\
\text { DNA extraction }\end{array}$ & Individual/pool DNA extraction \\
\hline Cereté & 1 (Cuero Curtido) & Hen's nest & $80^{7}, 40 \mathrm{~N}$ & $80^{7}$ & Adults individually \\
\hline Cereté & 3 (Severá) & Chicken nests & $21 \sigma^{7}, 6 o, 94 \mathrm{~N}$ & $30^{x}, 4 o, 10 \mathrm{~N}$ & $\begin{array}{l}\text { Adults individually/3 pools (one of } 2 \mathrm{~N} \text {; } \\
\text { two of } 4 \mathrm{~N} \text { ) }\end{array}$ \\
\hline San Carlos & 4 (Arroyo Negro) & Bahareque walls & $10^{7}, 3 q, 10 \mathrm{~N}$ & $10^{7}, 3 q, 10 \mathrm{~N}$ & $\begin{array}{l}\text { Adults individually } / 6 \text { pools (three of } \\
1 \mathrm{~N} ; \text { two of } 2 \mathrm{~N} \text {, one of } 3 \mathrm{~N} \text { ) }\end{array}$ \\
\hline Planeta Rica & 2 (El Espanto) & Bahareque wall & $2 \sigma^{x}, 4 \circ, 26 \mathrm{~L}$ & $2 \sigma^{\pi}, 3 q, 10 L$ & Adults individually/1 pool of $10 \mathrm{~L}$ \\
\hline Total & & & 215 & 54 & 34 \\
\hline
\end{tabular}

$o^{7}$, Males; o, Females; N, nymphs; L, Larvae.
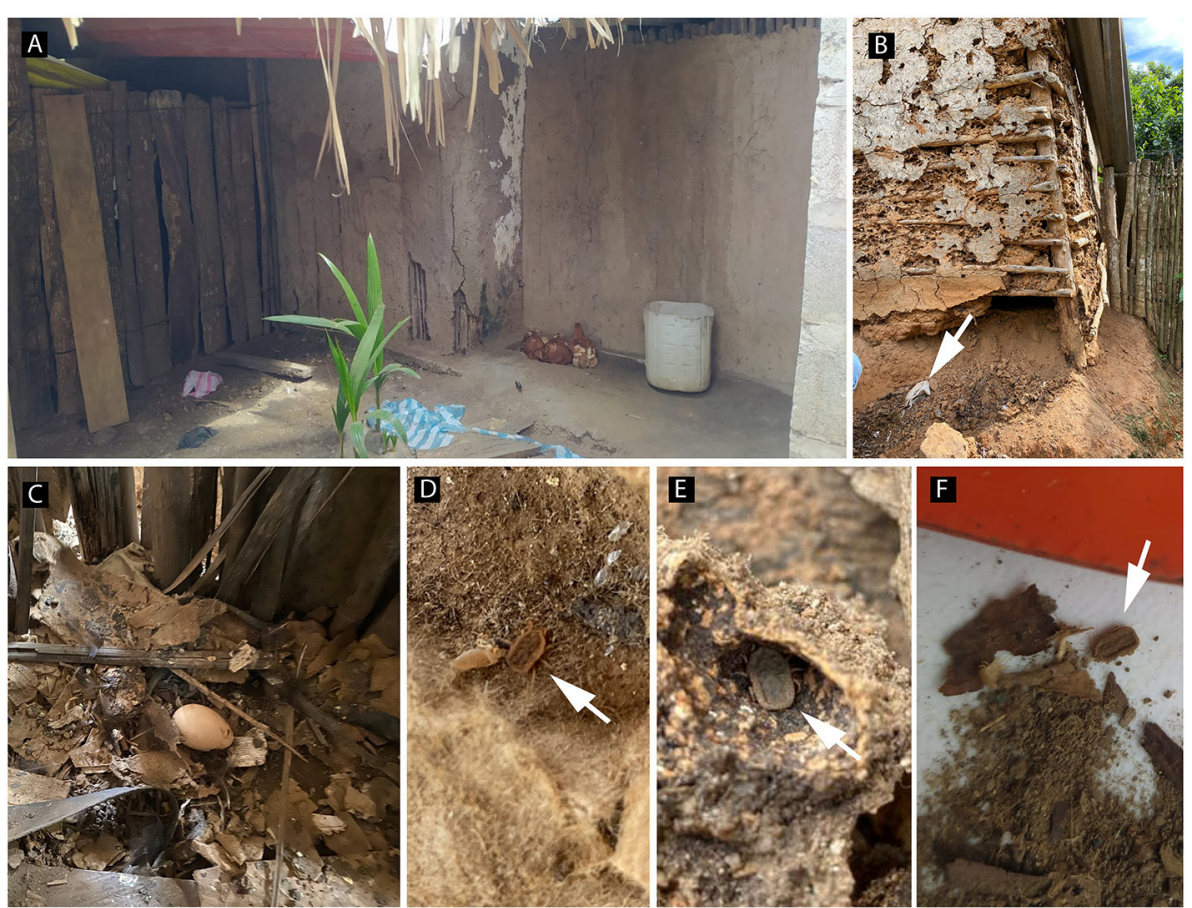

FIGURE 2 | Dwellings where soft ticks were collected in the Córdoba department, Colombia. (A) Chickens lying adjacent to an external bahareque wall in locality 4 (Arroyo Negro); (B) Bahareque construction; note the crevices on the wall and the bird nest (arrow) in locality 2 (El Espanto); (C) chicken nest adjacent to the wall inside a dwelling in locality 1 (Cuero Curtido); (D,F) Ornithodoros ticks (arrow) collected in fowl nest debris in locality 1 (Cuero Curtido) and locality 3 (Severá), respectively; (E) Ornithodoros ticks (arrow) collected in between bahareque debris from a dwellings wall in locality 2 (El Espanto).

adjacent to an external wall of a warehouse made of bahareque (Figure 2B). In this wall we collected 32 ticks (four females, two males, 26 larvae and a group of eggs) (Figure 2E). Interestingly, the owners of the warehouse recognized the ticks, named them as "Pitos," and also referred to bites of these arthropods while sleeping. In locality 3 a total of 121 ticks [27 adults (six females, 21 males) and 94 nymphs] were collected in chicken nests made of dried-banana-leaves, found in a warehouse and a kitchen, respectively, of two houses with guadua walls, dirt floor, and palm roof (Figure 2F). In locality 4, 14 ticks [four adults (three females and one male) and 10 nymphs] were collected in bahareque walls adjacent to chicken nests, in a warehouse and a room of two houses, respectively (Figure 2A).
Remarkably, domiciles where we found ticks were comparatively rudimental and precarious; had poor hygiene, and sanitary conditions; dirt in the most of their floors, and no record of recent pest chemical control.

\section{Morphological and Genetic Identification of Specimens}

Based on the examination of 10 slide mounted specimens, larvae were identified morphologically as $O$. puertoricensis because of the following combination of traits: dorsal plate pyriform; 17-18 pairs of dorsal setae (seven anterolateral, 6-7 posterolateral and four central); hypostome pointed, with dentition formula $3 / 3$ in middle length (Figures 3A-C). 


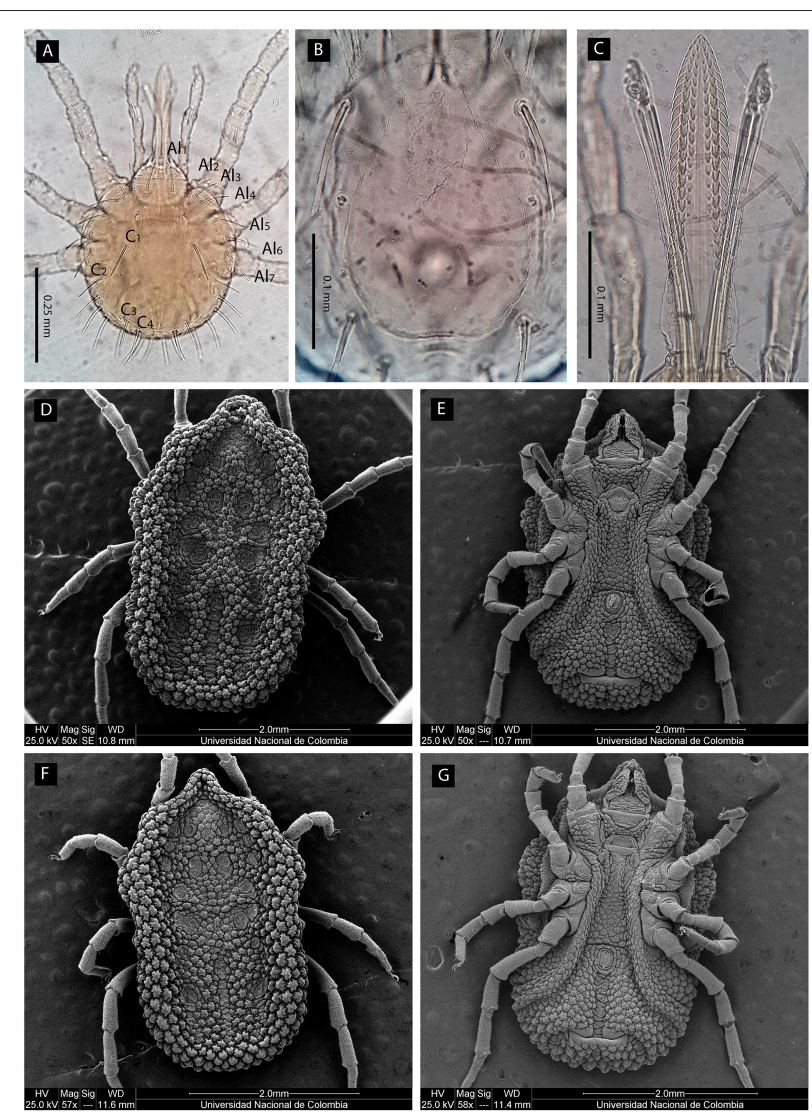

FIGURE 3 | Optical and scanning electron microscopic micrographs of $O$. puertoricensis collected in Córdoba department, Colombia. Larva: (A) dorsal view, (B) dorsal plate, and (C) hypostome. Female: (D) dorsal and (E) ventral views. Male: (F) dorsal and (G) ventral views. Al, anterolateral setae; C, central setae.

Nymphs and adults were identified morphologically as the same species by the combination of the following characters: presence of cheeks, conical mammillae, anteromedian disk present, posteromedian file of disks merging with median disk (Figures 3D-G). Examined larvae and adults were deposited in the "Colección Parasitológica Veterinaria Julio Mario Rodríguez Peña" at the Universidad Nacional de Colombia (UNAL: CPVUN: 2021ACAR001-003). Genetic identification of ticks was performed individually for 14 males, 10 females, nine pools of nymphs and one pool of larvae collected in the four localities (Table 1). Two haplotypes with two polymorphisms consisting of adenine-guanine transitions were retrieved (99.5\% of identity between them). Both sequences were 99.2-99.7\% identical to $O$. puertoricensis from Panama available in GenBank (KX685710) (35). Haplotype I was found in 28 pools of ticks (14 males, nine females and five pools of nymphs) from the four localities, while haplotype II was only found in six pools of ticks (one female, four pools of nymphs and one pool of larvae) from two of the localities (El Espanto and Arroyo Negro). Tick mitochondrial $16 \mathrm{~S}$ rDNA sequences of $O$. puertoricensis generated in this study were deposited in GenBank under accession numbers MZ005589 and MZ005590.

The phylogenetic analysis determined that O. puertoricensis from the Córdoba department in Colombia are closely related to a homologous species from Panama. A previous sequence of O. puertoricensis from Haiti (AF113932) branches basally to the Colombian and Panamanian ticks. Collectively, the sequences of $O$. puertoricensis cluster as a sister group to Ornithodoros cerradoensis (Figure 4). This topology is consistent with previous phylogenies including the $O$. talaje group (27).

\section{DISCUSSION}

This study reports for the first time O. puertoricensis infesting domestic fowl nests in rural dwellings in Colombia, and expands the geographical range of this tick species to the Córdoba department. However, O. puertoricensis is no stranger, since it has been reported in the northwestern region of the country. The first record of $O$. puertoricensis in Colombia was published by Fairchild in 1966, referring to adult specimens collected in the Ayacucho municipality, in Cesar department (20). Later, in 2009, Paternina et al. described the finding of larvae infesting dogs in the Sucre department (36), and recently, larvae and females were described infesting synanthropic rodents (i.e., Mus, Rattus) and human dwellings in Urabá region, in the Antioquia department $(19,37,38)$. In addition, Butler and Gibbs (39) stated that $O$. puertoricensis occurs in the Colombian pacific region as well.

Ornithodoros puertoricensis was described based on larvae collected on rats (Rattus spp.) in Puerto Rico (40). Moreover, amphibians, reptiles and mammals host larvae of $O$. puertoricensis in Jamaica (Herpestes javanicus, Nectomys sp., and Proechimys sp.), Panama (Rattus sp., Sylvilagus brasiliensis, Eyra barbara, Dasyprocta punctata, Felis silvestris catus, Rhinella marina, Varanus dumerilii, Python regius, Python bivittatus, and Homo sapiens), Trinidad (Proechimys trinitatus and Nectomys squamipes), Nicaragua (Dasyprocta punctata and Didelphis marsupialis), Venezuela (Proechimys guyannensis, Proechimys semispinosus, Dasyprocta fuliginosa, Sigmodon alstoni, Zygodontomys brevicauda, Sylvilagus floridanus, Tamandua tetradactyla, Conepatus semistriatus, Monodelphis brevicaudata, Marmosa robinsoni, Artibeus lituratus, Iguana sp., and unidentified lizard), and Puerto Rico (Felis silvestris catus) $(20,35,41-46)$. In particular, the sole record of O. puertoricensis associated with birds comes from Mexico, where larvae were collected on Speotyto cunicularia (29). Meanwhile, Dunn in 1931 collected larvae and adults of $O$. talaje on chickens and chicken coops in the Panama City market (20). Nevertheless, records of O. talaje in Panama prior to 1947 are questionable because of morphological confusion with O. puertoricensis (20,40). Dunn's descriptions are similar to our findings in that they suggest that Ornithodoros soft ticks do associate with domestic fowl. Even though in the present study we did not collect larvae feeding on animals, it is likely fowl could maintain the biological cycle of $O$. puertoricensis in the visited localities, since eggs, larvae, nymphs and adults were taken from their nests. Thus, our results suggest 


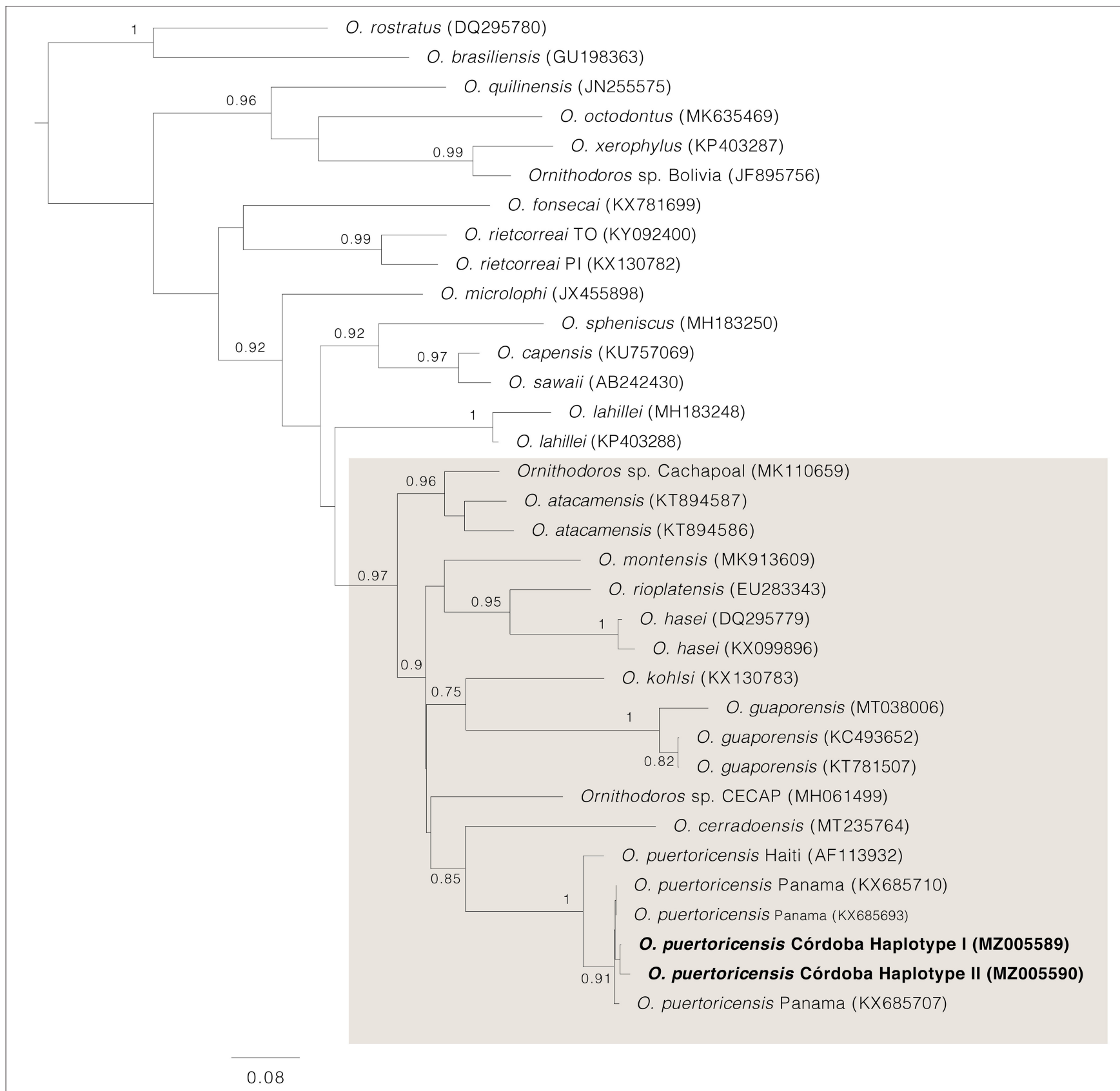

FIGURE 4 | Approximately maximum likelihood phylogenetic tree for a subset of Ornithodoros spp. Support values $>0.75$ are shown above or below main branches. The position of $O$. puertoricensis collected at Córdoba department is highlighted in bold. The $O$. talaje group is boxed in gray.

that the previous report of $O$. talaje made by Betancourt (21) at the same locations probably corresponds to O. puertoricensis.

Ornithodoros puertoricensis do infest human dwellings in Panama and Colombia $(19,35)$ and mild toxicosis was reported after their bites (35). Inside houses, O. puertoricensis seems to parasitize humans during the night (35). Indeed, during our investigations, the inhabitants of infested houses recognized the ticks and reported nocturnal parasitism as well. Interestingly, the common name for O. puertoricensis in the region (i.e., "Pito"), is the same one assigned to triatomine bugs, vectors of Chagas disease in Colombia (47). To acknowledge this coincidence in common names is valuable from an epidemiological point of view and in further inquiries looking for soft ticks infesting domiciliary environments in the region. Finally, evidence that $O$. puertoricensis transmits human pathogens is currently lacking. However, the role as a vector should not be ruled out, since other Ornithodoros ticks are reservoirs of TBRF spirochetes of human health concern. 


\section{DATA AVAILABILITY STATEMENT}

The datasets presented in this study can be found in online repositories. The names of the repository/repositories and accession number(s) can be found at: https://www.ncbi.nlm. nih.gov/genbank/, MZ005589; https://www.ncbi.nlm.nih.gov/ genbank/, MZ005590.

\section{AUTHOR CONTRIBUTIONS}

YL, SM-L, SM, and ÁF-M designed the initial study. YL, AA, and ÁF-M carried out the field work. YL, SM-L, LR-S, AR-H, and JC-V performed the tick identification and tick processing. YL, SM-L, EA, and ÁF-M implemented the molecular analysis.

\section{REFERENCES}

1. Gray A, Estrada-Peña A, Vial L. Ecology of nidicolous ticks. In: Sonenshine D, Roe R, editors. The Biology of Ticks. New York, NY: Oxford University Press (2014). p. 39-60.

2. Mans BJ, Gothe R, Neitz AWH. Biochemical perspectives on paralysis and other forms of toxicoses caused by ticks. Parasitology. (2004) 129:S95111. doi: $10.1017 /$ S0031182003004670

3. Dworkin M, Schwan T, Anderson D, Borchardt S. TickBorne relapsing fever mark. Infect Dis Clin North Am. (2008) 22:449-68. doi: 10.1016/j.idc.2008.03.006

4. Reck J, Marks FS, Guimarães JA, Termignoni C, Martins JR. Epidemiology of Ornithodoros brasiliensis (mouro tick) in the southern Brazilian highlands and the description of human and animal retrospective cases of tick parasitism. Ticks Tick Borne Dis. (2013) 4:101-9. doi: 10.1016/j.ttbdis.2012.09.004

5. Labruna MB, Venzal JM. Carios fonsecai sp. nov. (Acari, Argasidae), a bat tick from the central-western region of Brazil. Acta Parasitol. (2009) 54:35563. doi: 10.2478/s11686-009-0051-1

6. Labruna MB, Marcili A, Ogrzewalska M, Barros-Battesti DM, DantasTorres F, Fernandes AA, et al. New records and human parasitism by Ornithodoros mimon (Acari: Argasidae) in Brazil. J Med Entomol. (2014) 51:283-7. doi: 10.1603/ME13062

7. De Oliveira SV, Bitencourth K, Borsoi ABP, de Freitas FSS, Castelo Branco Coelho G, Amorim M, et al. Human parasitism and toxicosis by Ornithodoros rietcorreai (Acari: Argasidae) in an urban area of Northeastern Brazil. Ticks Tick Borne Dis. (2018) 9:1494-8. doi: 10.1016/j.ttbdis.2018.07.011

8. Venzal JM, Estrada-Peña A, Fernández De Luco D. Effects produced by the feeding of larvae of Ornithodoros aff. puertoricensis (Acari: Argasidae) on laboratory mice. Exp Appl Acarol. (2007) 42:217-23. doi: 10.1007/s10493-007-9089-7

9. Ribeiro CCDU, Faccini JLH, Cançado PHD, Piranda EM, Barros-Battesti DM, Leite RC. Life cycle of Ornithodoros rostratus (Acari: Argasidae) under experimental conditions and comments on the host-parasite relationship in the pantanal wetland region, Brazil. Exp Appl Acarol. (2013) 61:13946. doi: 10.1007/s10493-013-9669-7

10. Llanos-Soto S, Muñoz-Leal S, Gatica JL, Misad C, González-Acuña D. Human toxicosis caused by the tick Ornithodoros spheniscus in a chilean national park. Travel Med Infect Dis. (2020) 37:2019-21. doi: 10.1016/j.tmaid.2020.101811

11. Franco R, Toro G, Martínez J. Fiebre amarilla y fiebre espiroquetal. Ses Científicas del Centen Acad Nac Med Bogotá. (1911) 1:169-227.

12. Faccini-Martínez ÁA, Botero-García CA. Regarding tick-borne relapsing fever in the Americas; some historical aspects of a forgotten disease in Colombia. Vet Sci. (2016) 3:3-6. doi: 10.3390/vetsci304 0033

13. Pino-Pou R. La fiebre recurrente en general y particularmente en venezuela. Gac Med Caracas. (1921) 28:125-37.

14. Muñoz-Leal S, Marcili A, Fuentes-Castillo D, Ayala M, Labruna MB. A relapsing fever Borrelia and spotted fever Rickettsia in ticks from
YL, SM-L, and ÁF-M wrote the first draft of the manuscript. All authors contributed to data interpretation and revisions.

\section{FUNDING}

ÁF-M was supported by a Fogarty fellowship under Grant No. 2D43TW010331.

\section{ACKNOWLEDGMENTS}

We thank Dr. David H. Walker for providing constructive reviews of the manuscript. We are grateful to Yeimi López for preparing the maps of Figure 1. an Andean valley, central Chile. Exp Appl Acarol. (2019) 78:40320. doi: 10.1007/s10493-019-00389-x

15. Muñoz-Leal S, Faccini-Martínez ÁA, Teixeira BM, Martins MM, Serpa MCA, Oliveira GMB, et al. Relapsing fever group borreliae in human-biting soft ticks, Brazil. Emerg Infect Dis. (2021) 27:321-4. doi: 10.3201/eid2701.200349

16. Guglielmone A, Estrada A, Keirans J, Robbins R. Ticks (Acari: Ixodida: Argasidae, Ixodidae) Of the Neotropical Zoogeographic Region. A special publication sponsored by International Consortium on Ticks and Tick-borne Diseases (ICTTD-2). Atalanta, Houten, The Netherlands. (2003).

17. Dunn LH. Studies on the South American Tick, ornithodoros venezuelensis brumpt, in Colombia. Its prevalence, distribution, and importance as an intermediate host of relapsing fever. J Parasitol. (1927) 13:24955. doi: $10.2307 / 3271661$

18. Renjifo-Salcedo S, Osorno-Mesa E. Presencia de Ornithodoros Furcosus Neumann en Imués, Nariño y notas sobre el género Ornithodoros en Colombia. An la Soc Biol Bogotá. (1948) 3:112-23.

19. Quintero JC, Mignone J, Osorio QL, Cienfuegos-Gallet AV, Rojas AC. Housing conditions linked to tick (Ixodida: Ixodidae) infestation in rural areas of Colombia: a potential risk for rickettsial transmission. J Med Entomol. (2021) 58:439-49. doi: 10.1093/jme/tjaa159

20. Fairchild G, Kohls G, Tipton V. The ticks of panama (Acarina: Ixodoidea). Chicago, Ill: Field Museum of Natural History (1966). p. 167-219.

21. Betancourt A. Ornithodoros talaje en Córdoba. Monteria: Asociación Colombiana de Médicos Veterinarios y/o Zootecnistas, ACOVEZ-Córdoba (1980).

22. Venzal JM, Estrada-Peña A, Mangold AJ, González-Acuña D, Guglielmone AA. The Ornithodoros (Alectorobius) talaje species group (Acari: Ixodida: Argasidae): description of Ornithodoros (Alectorobius) rioplatensis $\mathrm{n}$. sp. from Southern South America. J Med Entomol. (2008) 45:832-40. doi: 10.1603/0022-2585 (2008) 45[832:TOATSG]2.0.CO;2

23. Hoogstraal H. Argasid and nuttalliellid ticks as parasites and vectors. $A d v$ Parasitol. (1985) 24:135-238. doi: 10.1016/S0065-308X(08)60563-1

24. Municipio de Planeta Rica. Plan De Desarrollo 20202023 - Región Identidad Agroindustria. Planeta Rica: Municipio de Planeta Rica (2020).

25. Municipio de San Carlos. Plan De Desarrollo Municipal 2020-2023-San Carlos-Córdoba. San Carlos: Municipio de San Carlos (2020).

26. Municipio De Cereté. Plan De Desarrollo "Desarrollo Económico Y Bienestar Social De Corazón Con La Gente" Para El Municipio De Cereté Durante El Periodo 2020-2023. Cereté: Municipio De Cereté (2020).

27. Muñoz-Leal S, Martins M, Nava S, Landulfo G, Simons S, Rodrigues $\mathrm{V}$, et al. Ornithodoros cerradoensis n. sp. (Acari: Argasidae), a member of the Ornithodoros talaje (Guérin-Méneville, 1849) group, parasite of rodents in the Brazilian Savannah. Ticks Tick Borne Dis. (2020) 11:101497. doi: 10.1016/j.ttbdis.2020.101497

28. Kohls G, Sonenshine D, Clifford C. The systematics of the subfamily Ornithodorinae (Acarina: Argasidae). II. Identification of the larvae of the western hemisphere and descriptions of three new species. Entomol Soc Am. (1965) 58:331-64. doi: 10.1093/aesa/58.3.331 
29. Endris RG, Keirans JE, Robbins RG, Hess WR. Ornithodoros (Alectorobius) puertoricensis (Acari: Argasidae): redescription by scanning electron microscopy. J Med Entomol. (1989) 26:146-54. doi: 10.1093/jmedent/26.3.146

30. Mangold AJ, Bargues MD, Mas-Coma S. Mitochondrial 16S rDNA sequences and phylogenetic relationships of species of Rhipicephalus and other tick genera among Metastriata (Acari: Ixodidae). Parasitol Res. (1998) 84:47884. doi: 10.1007/s004360050433

31. Kearse M, Moir R, Wilson A, Stones-Havas S, Cheung M, Sturrock S, et al. Geneious basic: an integrated and extendable desktop software platform for the organization and analysis of sequence data. Bioinformatics. (2012) 28:1647-9. doi: 10.1093/bioinformatics/bts199

32. Altschul SF, Gish W, Miller W, Myers EW, Lipman DJ. Basic local alignment search tool. J Mol Biol. (1990) 215:40310. doi: 10.1016/S0022-2836(05)80360-2

33. Katoh K, Misawa K, Kuma KI, Miyata T. MAFFT: a novel method for rapid multiple sequence alignment based on fast fourier transform. Nucleic Acids Res. (2002) 30:3059-66. doi: 10.1093/nar/gkf436

34. Price MN, Dehal PS, Arkin AP. FastTree 2 - approximately maximum-likelihood trees for large alignments. PLoS ONE. (2010) 5:e9490. doi: 10.1371/journal.pone.0009490

35. Bermúdez SE, Castillo E, Pohlenz TD, Kneubehl A, Krishnavajhala A, Domínguez L, et al. New records of Ornithodoros puertoricensis fox 1947 (Ixodida: Argasidae) parasitizing humans in rural and urban dwellings, Panama. Ticks Tick Borne Dis. (2017) 8:466-9. doi: 10.1016/j.ttbdis.2017.02.004

36. Paternina LE, Díaz-Olmos Y, Paternina-Gómez M, Bejarano EE. Canis familiaris, un nuevo hospedero de Ornithodoros (A.) puertoricensis fox, 1947 (Acari: Ixodida) en Colombia. Acta Biol Colomb. (2009) 14:153-60.

37. Quintero JC, Londoño AF, Díaz FJ, Agudelo-Flórez P, Arboleda M, Rodas JD. Ecoepidemiología de la infección por rickettsias en roedores, ectoparásitos y humanos en el noroeste de Antioquia, Colombia. Biomedica. (2013) 33:3851. doi: 10.7705/biomedica.v33i0.735

38. Londoño AF, Acevedo-Gutiérrez Y, Marín D, Contreras V, Díaz FJ, Valbuena $\mathrm{G}$, et al. Wild and domestic animals likely involved in rickettsial endemic zones of Northwestern Colombia. Ticks Tick Borne Dis. (2017) 8:88794. doi: 10.1016/j.ttbdis.2017.07.007

39. Butler JF, Gibbs EPJ. Distribution of potential soft tick vectors of African swine fever in the Caribbean region (Acari: Argasidae). Prev Vet Med. (1984) 2:63-70. doi: 10.1016/0167-5877(84)90049-7
40. Fox I. Ornithodoros puertoricensis, a new tick from rats in puerto rico. Am Soc Parasitol. (1947) 33:253-9. doi: 10.2307/3273558

41. Webb JW. Parasites of small indian mongoose on St. Croix, Virgin islands. J Parasitol. (1980) 66:176-8. doi: 10.2307/3280620

42. Jones EK, Clifford CM, Keirans JE, Kohls GM. The ticks of venezuela (Acarina: Ixodoidea) with a key to the species of Amblyomma in the western hemisphere. Brigham Young Univ Sci Bull Biol Ser. (1972) 17:1-40.

43. Fox I. The domestic, felis catus 1., a new host record for the tick Ornithodoros Puertoricensis. Dep Med Zool Sch Med Univ Puerto Rico. (1977) 1:509. doi: 10.46429/jaupr.v61i4.10417

44. Bermúdez SE, Miranda RJ, Smith D. Ticks species (Ixodida) in the summit municipal park and adjacent areas, Panama City, Panama. Exp Appl Acarol. (2010) 52:439-48. doi: 10.1007/s10493-010-9374-8

45. Bermúdez SE, Miranda RJ, Kadoch SN. Reporte de larvas de Ornithodoros puertoricensis fox 1947 (Ixodida: Argasidae) parasitando a Rhinella marina (L. 1758) (Anura: Bufonidae) en David, Chiriquí, Panamá. Puente Biol. (2013). 5:81-5.

46. Bermúdez S, Miranda RJ, Cleghorn J, Venzal JM. Ornithodoros (Alectorobius) puertoricensis (Ixodida: Argasidae) parasitizing exotic reptile pets in Panama. FAVE Sección Ciencias Vet. (2015) 14:1-5. doi: 10.14409/favecv.v14i1/ 3.5095

47. Peña-García VH, Gómez-Palacio AM, Triana-Chávez O, Mejía-Jaramillo AM. Eco-epidemiology of chagas disease in an endemic area of Colombia: risk factor estimation, Trypanosoma cruzi characterization and identification of blood-meal sources in bugs. Am J Trop Med Hyg. (2014) 91:1116-24. doi: 10.4269/ajtmh.14-0112

Conflict of Interest: The authors declare that the research was conducted in the absence of any commercial or financial relationships that could be construed as a potential conflict of interest.

Copyright (C) 2021 López, Robayo-Sánchez, Muñoz-Leal, Aleman, Arroyave Ramírez-Hernández, Cortés-Vecino, Mattar and Faccini-Martínez. This is an openaccess article distributed under the terms of the Creative Commons Attribution License (CC BY). The use, distribution or reproduction in other forums is permitted, provided the original author(s) and the copyright owner(s) are credited and that the original publication in this journal is cited, in accordance with accepted academic practice. No use, distribution or reproduction is permitted which does not comply with these terms. 